DOI https://doi.org/10.36059/978-966-397-244-2-2-7

\author{
Легеза Ю. 0. \\ доктор юридичних наук, професор, \\ професор кафедри цивільного, господарського \\ та екологічного права \\ Інститут гуманітарних і соціальних наук \\ Національного технічного університету «Дніпровська політехніка» \\ м. Дніпро, Україна

\section{ПРАВО НА БЕЗПЕЧНЕ ДОВКІЛЛЯ: ПРОБЛЕМИ НОРМАТИВНОГО ВИЗНАЧЕННЯ ТА ЗАХИСТУ}

Метою даного дослідження $\epsilon$ встановлення сутності нормативного розуміння категорії «право на безпечне довкілля» та визначення напрямів забезпечення ефективності їі реалізації та захисту. Завданнями даного дослідження визначено: 1) встановлення сутності категорії «право на безпечне довкілля»; 2) характеристика публічного інтересу та права особи на безпечне довкілля; 3) здійснення характеристики права на доступ до екологічної інформації як складової частини механізму реалізації та захисту права особи на безпечне довкілля. Правом особи на безпечне довкілля обгрунтовано у розумінні права особи на забезпечення сприятливості антропогенного та природного навколишнього середовища, що характеризується показниками ефективності здійснення використання природних ресурсів на засадах раціональності та екологічності, стану охорони здоров'я населення тощо. Проблемами ефективності реалізації та захисту права особи на безпечне довкілля обгрунтовано: 1) нормативна колізійність підходів до його розуміння відповідно до положень чинного національного законодавства України та світових стандартів; 2) стагнація систематизаційних процесів у сфері використання природних ресурсів та охорони навколишнього природного середовища; 3) поліаспектність предметної національної судової юрисдикції, що спричинює неоднозначність підходів до їі застосування; 4) недосконалість механізму захисту публічного інтересу, зокрема, у частині залучення зацікавленої громадськості як його носія; 5) доцільність перегляду підходів до розуміння предмету доказування у справах про порушення права 
особи на безпечне довкілля, що покладається на носіїв такого права чи інтересу, а не на осіб, які порушили суб'єктивні екологічні права або ж вимоги екологічного законодавства, не створили умов для їх належної реалізації, не забезпечили виконання встановлених вимог суб'єктами господарювання щодо раціонального використання природних ресурсів, охорони довкілля та забезпечення екологічної безпеки.

\section{Вступ}

Відповідно до показників системи Індексу екологічної ефективності, оприлюднених у 2020 р., Україна обіймає 60-ту позицію з-поміж 180 країн світу, перебуваючи між такими країнами «третього» світу, як Зімбабве, Антигуа і Барбуда, Гондурас. Однак при цьому такий показник свідчить про певні позитивні тенденції у забезпеченні права особи на безпечне навколишнє середовище [1]. Індексом екологічної ефективності $\epsilon$ (Environmental Performance Index, EPI) $\epsilon$ один значимих індикаторів міжнародної рейтингової системи оцінювання безпеки довкілля, що визначається як комплексний показник оцінки екологічної політики держави та ії окремих суб'єктів, при цьому він розраховується за 24 показниками ефективності за десятьма категоріями, серед яких виділяються не лише дотримання стандартів безпеки та раціональності використання природних ресурсів, а і показники стану здоров'я населення та життєздатності екологічної системи [2]. Згідно із обгрунтованою оцінкою Національного інституту стратегічних досліджень існування наявної ситуації в майбутньому створює негативні «передумови» для формування значних екологічних загроз і збільшення кількості надзвичайних ситуацій 3 негативними наслідками для населення та навколишнього природного середовища зокрема, і в цілому в межах світового масштабу.

При цьому відповідно до чинного законодавства України нормативно механізм реалізації та захисту права на безпечне довкілля $є$ недосконалим і таким, що не відповідає складній сукупності стандартів його регулювання у країнах Європейського Союзу, що підтверджується як прогалинами та колізійністю підходів до його закріплення, так і результатами практики національної системи судоустрою, що визначає актуальність даної наукової праці. 
Метою даного дослідження $\epsilon$ встановлення сутності нормативного розуміння категорії «право на безпечне довкілля» та визначення напрямів забезпечення ефективності її реалізації та захисту.

\section{1. Нормативне визначення категорії «право на безпечне довкілля»}

Конституція України містить окремі положення, що визначають основоположні засади механізму реалізації та захисту на безпечне довкілля. Право на безпечне для життя та здоров'я людини довкілля визначено Конституцією України як одне із основних прав кожного, до складових якої поряд із забезпеченням із інформацією про стан охорони навколишнього природного середовища відноситься інформація про стан та якість продуктів харчування та предметів побуту (ст. 50) [3].

Згідно із статтями 13, 14 Конституції України визначається, що земля, водні ресурси є об'єктом права власності Українського народу, від імені якого права власника здійснюють органи державної влади та органи місцевого самоврядування в межах, визначених чинним законодавством. Земля $\epsilon$ основним національним багатством, що перебуває під особливою охороною держави. Право власності на землю набувається і реалізується громадянами, юридичними особами та державою виключно відповідно до закону.

Статтею 16 Конституції України закріплюється положення, що «забезпечення екологічної безпеки і підтримання екологічної рівноваги на території України, подолання наслідків Чорнобильської катастрофи - катастрофи планетарного масштабу, збереження генофонду Українського народу $\epsilon$ обов'язком держави».

Визначений нормативний підхід, встановлений Конституцією України, спричинив доцільність перегляду розуміння категорії навколишнього природного середовища як сукупності природних ресурсів та стану їх використання, що тривалий час було відносно сталою категорією як складової частини побудови національної правової системи. Наявний законодавчий підхід до розуміння категорії «довкілля» допускає їі розширене тлумачення, в аспекті доцільності поєднання не лише природного середовища, a i антропогенного як середовища життєдіяльності людини. 
Відтак необхідно підкреслити, що доцільним $\epsilon$ розуміння природного довкілля як сукупності природних об'єктів та ресурсів, які мають бути використовуватися на засадах раціональності, ефективності та економічності задля створення умов їх збереження та відновлення у майбутньому. Забезпечення безпеки навколишнього природного середовища має переслідувати нормативну мету «здійснення охорони, використання і відтворення природних ресурсів, забезпечення екологічної безпеки, запобігання і ліквідації негативного впливу господарської та іншої діяльності на навколишнє природне середовище, збереження природних ресурсів, генетичного фонду живої природи, ландшафтів та інших природних комплексів, унікальних територій та природних об'єктів, пов'язаних 3 історико-культурною спадщиною» [4].

На законодавчому рівні $€$ відсутнім закріплення розуміння категорії «антропогенне довкілля», що вимагає звернення до результатів наукових досліджень його сутності. Ряд дослідників обгрунтовують необхідність виокремлення та нормативного закріплення поняття «антропогенне довкілля» як середовища, що перебуває під негативним шкідливим впливом, що заподіюється внаслідок здійснення господарської діяльності чи інших видів діяльності особи (зокрема, розміщення безхазяйних відходів) [5, с. 106-119; 6, с. 50-57]. Ефективність екологічної безпеки антропогенного довкілля пов'язується із впровадженням «якісних» умов праці, проживання, приватного життя, навчання, безпечних продуктів харчування, сертифікованих медичних засобів. Такий підхід корелюється із визнаним світовою спільнотою Індексом екологічної ефективності.

За рівнем відповідності стандартам екологічної безпеки довкілля, як природне, так i антропогенне, може бути охарактеризувати як абсолютно сприятливе, відносно сприятливе чи несприятливе. При цьому всі ці рівні довкілля за своєю сутністю можуть відповідати вимогам екологічної безпеки, а тому мають визнаватися у судовому порядку безпечним.

Вартою уваги є підхід Ю.М. Шемшученко та В.В. Костицького до розуміння категорії «сприятливе довкілля», як довкілля безпечного для життя та здоров'я людини [20], фактично ототожнюючи категорії «безпечний» та «сприятливий». Категорія «сприятливе довкілля» $\epsilon$ вживаною та характерною для національного законодавства України. Зокрема, відповідно до ч. 3 
ст. 5 Закону України «Про охорону навколишнього природного середовища» визначено, що функціонування системи публічного управління своєю метою має забезпечення та вжиття заходів із державної охорони довкілля від шкоди, що може бути заподіяна життю та здоров'я людей [4]. Законом України «Про охорону навколишнього природного середовища» безпосередньо закріплено забезпечення сприятливості довкілля пов'язується із збереженням та охороною «природних територій та об'єктів, що мають велику екологічну цінність як унікальні та типові природні комплекси» (ч. 1 ст. 60) [4]. Відповідно до положень ч. 2 ст. 62 Закону України «Про охорону навколишнього природного середовища» віднесено до об'єктів, що характеризують довкілля як сприятливе належність в ньому природних об'єктів, що мають курортне, рекреаційне призначення, використання яких здатне вирішити задачу із відновлення здоров'я людини - психічного, морального та фізіологічного [4].

Категорію «сприятливе» довкілля використовують і ратифіковані України міжнародні правові акти. Зокрема, відповідно до Стокгольмської декларації 3 навколишнього середовища визначено право людини на сприятливі умови життя у навколишньому середовищі, якість якого дозволяє вести гідне та процвітаюче життя [7]. Стокгольмська декларація 3 навколишнього середовища 1972 р. закріплює право людини на сприятливі умови життя у навколишньому середовищі, якість якого дозволяє вести гідне та процвітаюче життя [7].

Відповідно до ч. 4 ст. 5 Орхуської конвенції визначено зобов'язання держав не рідше одного разу на три або чотири роки оприлюднювати національні звіти про стан навколишнього середовища, включаючи інформацію про якість навколишнього середовища та інформацію щодо навантажень на навколишнє середовище [8].

Натомість відповідно до чинного законодавства України не визначено розуміння категорії «якість навколишнього середовища».

Забезпечення сприятливості навколишнього природного середовища вимагає не лише дотримання вимоги досягнення визначених світових стандартів екологічної безпеки, але такі показники антропогенного забруднення довкілля як кореляційні зв'язки між тривалістю життя людини та рівнем шкідливих викидів у атмосферне повітря тощо. Необхідно підкреслити, що 
застосування таких показників належним чином відображує характер шкідливого впливу, що заподіюється від господарської діяльності не лише природі, а і життю та здоров'ю.

Однак такий підхід поєднання антропогенної та природної складової навколишнього природного середовища не знайшов підтримки у національному правовому полі. Домінуючим натомість $€$ розуміння довкілля як навколишнього природного середовища у розуміння певної сукупності природних ресурсів та природних об'єктів.

Суперечливим $\epsilon$ підхід щодо доцільності розуміння права людини на безпечне для життя та здоров'я довкілля як права на дотримання лише вимог раціональності використання природних ресурсів та природних об'єктів. Вважаємо, базисом забезпечення безпеки навколишнього середовища для життя та здоров'я людини має бути не лише показники безпечності використання природних ресурсів, а певні показники життєдіяльності суспільства в цілому, і зокрема, людини, що свідчить про загрозливий стан довкілля регіону.

Навколишнє середовище має розглядатися як безумовна складова показників якості життя людини, що безумовно впливає на його тривалість. Елементами довкілля мають бути визнані не лише природні ресурси та природні об'єкти, а і інші показники, що свідчать про належний рівень благоустрою населених пунктів, до розуміння якого відноситься дотримання природоохоронних, естетичних, містобудівельних та інших норм та стандартів, що складає антропогенну складову навколишнього середовища.

Отже, категорія «безпечне довкілля» має враховувати не лише кількісні показники, але і якісні. Безпечним довкіллям має визнаватися довкілля, що сприяє відпочинку людини, відновленню стану її фізичного та психічного здоров'я. Ознака безпечності довкілля втім вказує передусім на граничну межу забезпечення стану, за умови існування якого не заподіюється шкідливий вплив для життя та здоров'я людини. Ознакою сприятливості довкілля $є$ створення умов для його відновлення, забезпечення високого рівня життєдіяльності людини, що пов'язується із тривалістю їі життя, статистичними показниками народжуваності населення, задоволення його естетичних, рекреаційних, культурних та інших потреб.

В такому розрізі $\epsilon$ доцільним звернути увагу на виокремлену теорію «права людини на здорове довкілля». 
Система нормативного закріплення права особи на безпечне довкілля має декілька складових. Першу групу складають законодавчі акти, що визначають особливості забезпечення раціонального використання природних ресурсів. Необхідно підкреслити, що всі природні ресурси відповідно до чинного законодавства поділяються на природні ресурси загальнодержавного (нафта, газ, ліси природо-заповідного фонду, природні об'єкти, що перебувають у виключній власності держави і не можуть бути передані в комунальну чи приватну власність) та місцевого значення (глина, вапняк, пісок).

До природних ресурсів загальнодержавного значення належать:

а) внутрішні морські води та територіальне море;

б) природні ресурси континентального шельфу та виключної (морської) економічної зони;

в) атмосферне повітря;

г) підземні води;

д) поверхневі води, що знаходяться або використовуються на території більш як однієї області;

е) лісові ресурси державного значення;

є) природні ресурси в межах територій та об'єктів природнозаповідного фонду загальнодержавного значення;

ж) дикі тварини, які перебувають у стані природної волі в межах території України, iї континентального шельфу та виключної (морської) економічної зони, інші об'єкти тваринного світу, на які поширюється дія Закону України «Про тваринний світ» і які перебувають у державній власності, а також об'єкти тваринного світу, що у встановленому законодавством порядку набуті в комунальну або приватну власність і визнані об'єктами загальнодержавного значення;

з) корисні копалини, за винятком загальнопоширених (ст. 39 Закону України «Про охорону навколишнього природного середовища») [4].

Законодавством України можуть бути віднесені до природних ресурсів загальнодержавного значення й інші природні ресурси.

Визначення порядку набуття спеціальних прав на використання природних ресурсів загальнодержавного значення встановлюється на підзаконному нормативно-правовому рівні (зокрема, таким актом $є$ Постанова КМ України «Про порядок видачі дозволів на спеціальне використання природних ресурсів 
у межах територій та об'єктів природно-заповідного фонду і встановлення лімітів використання ресурсів загальнодержавного значення» від 10 серпня 1992 р. № 459) та ін.

Такий підхід протирічить конституційним вимогам (ст.ст. 13, 14), що підстави набуття права власності на природні ресурси мають встановлюватися на законодавчому рівні.

До природоресурсного законодавства відносяться ряд кодифікованих нормативно-правових актів, зокрема, Земельний кодекс України [9], Водний кодекс України [10], Кодекс України про надра [11], Лісовий кодекс України [12]. В цьому сенсі варто підкреслити, що тривалий час доволі жваво обговорювалась ідея розробки та прийняття Екологічного кодексу $[13$, с. $148 ; 14$, c. 214-216]. В.В. Копєйчиков у розрізі дослідження проблеми кодифікації матеріальних та процесуальних норм чинного законодавства України обгрунтовував, зокрема, доцільність активізації процесів із систематизації законодавства у сфері реалізації та захисту права особи на безпечне довкілля, що, на його думку, визначає «корисність Екологічного кодексу України» для національної правової системи [13, с. 44-52].

Підтримана ідея розуміння Екологічного кодексу України як невід'ємної складової національної правової системи України у наукових працях Л.Р. Наливайко, яка наголошувала, що його розробка сприятиме вирішенню задачі забезпечення зручності та корисності чинного законодавства як критеріїв його ефективності [14, с. 226; 15, с. 181-185].

Альтернативним був науково-теоретичний підхід щодо доцільності розробки та прийняття Природоресурсного кодексу України [16, с. 87-88; 17, с. 8-9; 18, с. 158-160].

На разі, попри наявні позитивні практики розробки та прийняття Екологічного чи Природоресурсного Кодексів (зокрема, такі акти успішно діють в Республіці Казахстан [19]), в Україні такого акта і досі не запроваджено [20].

Необхідно підкреслити, що подолання наявних проблем систематизації чинного законодавства України з питань захисту права особи на безпечне довкілля залежить від впровадження існуючих міжнародних стандартів, його відповідності стандартам законодавства країн Європейського Союзу [21].

Другу групу системи законодавства 3 питань забезпечення реалізації та захисту права людини на безпечне довкілля $\epsilon$ законодавство у сфері забезпечення вимог екологічності та 
сприятливості довкілля, до якого відносяться Закони України «Про мораторій на проведення суцільних рубок на гірських схилах в ялицево-букових лісах Карпатського регіону», «Про ратифікацію Протоколу про сталий транспорт до Рамкової конвенції про охорону та сталий розвиток Карпат», «Про оцінку впливу на довкілля», «Про основи національної безпеки України», «Про охорону навколишнього природного середовища», «Про зону надзвичайної екологічної ситуації», «Про використання ядерної енергії та радіаційну безпеку», «Про стандартизацію», «Про захист прав споживачів», «Про якість і безпеку харчових продуктів i продовольчої сировини», «Про поводження 3 радіоактивними відходами», «Про курорти», «Про охорону культурної спадщини», «Про регулювання містобудівної діяльності», «Про об'єкти підвищеної екологічної небезпеки» та ін.

Третю групу законодавства 3 питань реалізації та захисту права людини на безпечне довкілля відносяться нормативні правові акти, що визначають здійснення права особи на доступ до екологічної інформації, серед яких необхідно виділити Закони України «Про доступ до публічної інформації», «Про інформацію», «Про телебачення та радіомовлення», «Про друковані засоби інформацію (пресу)», «Про національну інфраструктуру геопросторових даних», «Про топографо-геодезичну і картографічну діяльність», «Про Державний земельний кадастр» та ін.

Останню групу нормативно-правових актів у сфері реалізації та захисту права особи на безпечне довкілля складають міжнародні акти, до яких відносяться такі природоохоронні та природоресурсні конвенції та протоколи до них, як: Загальна декларація прав людини, Європейська Конвенція з прав людини, Орхуська конвенція, Конвенція ООН по боротьбі із засухою; Конвенція про ядерну безпеку; Конвенція з біорізноманіття; Рамкова конвенція 3 охорони та збалансованого розвитку Карпат; Конвенція про міжнародну торгівлю видами дикої фауни та флори, що перебувають під загрозою вимирання; Конвенція про збереження мігруючих видів диких тварин (Боннська конвенція); Конвенція з захисту Чорного моря від забруднення; Європейська ландшафтна конвенція; Конвенція про охорону дикої флори та фауни, а також природного середовища в Європі (Бернська конвенція). 
Новітні досягнення та вектори розвитку сучасної юриспруденції

\section{2. Публічний інтерес та право особи на безпечне довкілля}

Судовий контроль у сфері реалізації права на безпечне довкілля повинен бути спрямований на вирішення задачі досягнення балансу приватного та публічного інтересу у використанні та охороні природних ресурсів.

Нормативного визначення категорії «публічний інтерес» поки що не вироблено. Згідно із положеннями проєкту Закону України «Про адміністративну процедуру» [22] під публічним інтересом розуміється «інтерес держави, суспільства, територіальної громади, а також важливі для значної кількості осіб інтереси та потреби».

Виходячи із матеріалів національної судової практики публічним потребами розглядається відновлення законності під час вирішенні суспільно важливого та соціально значущого питання - використання природних об'єктів та природних ресурсів загальнодержавного значення на засадах домінування суспільного інтересу.

Право на справедливий суд також не може бути обмежено, проте, визначаючи справедливий баланс між правом особи на безпечне для життя i здоров`я довкілля та правом на справедливий суд, слід зазначити про пріоритет природного права особи на життя та безпечне довкілля, яке визнається таким усіма цивілізованими народами і націями та є загальним спадком європейської правової традиції, позитивний обов язок щодо забезпечення якого на території України покладено на державу Україна. Так, утвердження і забезпечення прав і свобод людини є головним обов язком держави (стаття 1 Конституції України).

При цьому відповідно до частини 1 рішення Конституційного суду України від 01.12.2004 року у справі № 1-10/2004 поняття «охоронюваний законом інтерес», що вживається в частині першій статті 4 Цивільного процесуального кодексу України та інших законах України у логічно-смисловому зв язку з поняттям «права», треба розуміти як прагнення до користування конкретним матеріальним та/або нематеріальним благом, як зумовлений загальним змістом об`єктивного і прямо не опосередкований у суб`єктивному праві простий легітимний дозвіл, що є самостійним об`єктом судового захисту та інших засобів правової охорони з метою задоволення індивідуальних і колективних потреб, які не суперечать Конституції України i 
Новітні досягнення та вектори розвитку сучасної юриспруденції

законам України, суспільним інтересам, справедливості, добросовісності, розумності та іншим загально правовим засадам [23].

Згідно із статтею 50 Конституції України встановлюється право кожного на безпечне для життя і здоров`я довкілля та на відшкодування завданої порушенням цього права шкоди. Екологічні інтереси населення можуть підлягати судовому захисту на підставі частини сьомої статті 41 Конституції України, відповідно до якої використання власності не може завдавати шкоди правам, свободам та гідності громадян, інтересам суспільства, погіршувати екологічну ситуацію та природні якості землі, а також приписів статті 66 Основного Закону, відповідно до якої ніхто не повинен заподіювати шкоду довкіллю.

Захист права особи на безпечне довкілля допускається у порядку господарського, адміністративного та цивільного судочинства України. Так, відповідно до положень постанови Північного апеляційного господарського суду у справі № 911/3447/17 від 29 січня 2019 року [24] визначено, що використання земель природо-заповідного фонду критеріям належності та виправданості втручання держави в право власності особи є виправданим, якщо воно здійснюється з метою задоволення «суспільного», «публічного» інтересу, при визначенні якого ЄСПЛ надає державам право користуватися «значною свободою (полем) розсуду». Втручання держави в право на мирне володіння майном може бути виправдане за наявності об'єктивної необхідності у формі суспільного, публічного, загального інтересу, який може включати інтерес держави, окремих регіонів, громад чи сфер людської діяльності.

У зазначеній справі було обгрунтовано, правовідносини, пов'язані 3 вибуттям земель із державної чи комунальної власності, становлять «суспільний», «публічний» інтерес, а незаконність (якщо така буде встановлена) рішення органу виконавчої влади або органу місцевого самоврядування, на підставі якого земельна ділянка вибула 3 державної чи комунальної власності, такому суспільному інтересу не відповідає.

Згідно 3 частинами другою та третьою статті 1, частиною першою та другою статті 7 Лісового кодексу України визначено, що ліси $\epsilon$ ії національним багатством і за своїм призначенням та місцерозташуванням виконують переважно водоохоронні, захисні, санітарно-гігієнічні, оздоровчі, рекреаційні, естетичні, 
виховні, інші функції та є джерелом для задоволення потреб суспільства в лісових ресурсах. Усі ліси на території України, незалежно від того, на землях яких категорій за основним цільовим призначенням вони зростають, та незалежно від права власності на них, становлять лісовий фонд України і перебувають під охороною держави. Ліси, які знаходяться в межах території України, є об'єктами права власності Українського народу. Від імені Українського народу права власника на ліси здійснюють органи державної влади та органи місцевого самоврядування в межах, визначених Конституцією України.

Іншою судовою практикою $\epsilon$ рішення Північного апеляційного господарського суду від «01» липня 2020 р. у справі № 910/4254/20, де визначено, що реалізація права власності на землю Українського народу, ліси як національного багатства України, зміни цільового призначення земель лісового фонду та безоплатної передачі у власність громадянам земельних ділянок і лісів із державного власності має відповідати вимогам захисту суспільних (публічних) інтересів.

«Суспільний», «публічний» інтерес полягає у відновленні правового порядку в частині визначення меж компетенції органів державної влади та місцевого самоврядування, відновленні становища, яке існувало до порушення права власності Українського народу на землі лісогосподарського призначення, захист такого права шляхом повернення в державну власність земель лісогосподарського призначення, що незаконно вибули з такої власності.

Колегія суддів звертає увагу на те, що у спорах стосовно прибережних захисних смуг, земель лісогосподарського призначення, інших земель, які перебувають під посиленою правовою охороною держави, остання, втручаючись у право мирного володіння відповідними земельними ділянками з боку приватних осіб, може захищати загальні інтереси у безпечному довкіллі, непогіршенні екологічної ситуації, у використанні власності не на шкоду людині та суспільству (частина 3 статті 13, частина 7 статті 41, частина 1 статті 50 Конституції України). Ці інтереси реалізуються, зокрема, через цільовий характер використання земельних ділянок (статті 18, 19, пункт «а» частини 1 статті 91 Земельного кодексу України), які набуваються лише згідно із законом (стаття 14 Конституції України). 
Зокрема, у зазначеній справі суд апеляційної інстанції дійшов до висновку, що «суспільним», «публічним» інтересом виступає звернення першого заступника прокурора Київської області 3 вимогою про витребування спірної земельної ділянки із володіння ТОВ «Грінінвест» у цій справі $є$ задоволення суспільної потреби у відновленні законності під час вирішенні суспільно важливого та соціально значущого питання - зміни цільового призначення земель лісового фонду та безоплатної передачі у власність громадянам земельних ділянок і лісів із державного власності, а також захист суспільних інтересів загалом, права власності на землю Українського народу, лісів - національного багатства України та лісів, як джерела задоволення потреб суспільства в лісових ресурсах.

Реалізація ідеї справедливості ЄСПЛ розглядається як необхідність дотримання балансу публічного та приватного інтересів (рішення в справах «Спорронг і Льоннорт проти Швеції», «Булвес» АД проти Болгарії»).

Отже, стосовно землі лісогосподарського призначення закон установлює пріоритет державної, комунальної власності на землю над приватною і, крім того, прямо забороняє органам місцевого самоврядування та органам виконавчої влади передавати в приватну власність ліси та землю відповідного цільового призначення поза складом угідь селянських, фермерських та інших господарств, або й у складі цих угідь, якщо площа ділянки більше, ніж 5 га.

Земельні ділянки зелених зон і зелених насаджень міст належать до земель рекреаційного призначення (стаття 51 Земельного кодексу України). На цих землях забороняється діяльність, що перешкоджає або може перешкоджати використанню їх за призначенням, а також негативно впливає або може вплинути на природний стан цих земель (частина 3 статті 52 Земельного кодексу України).

Колегія суддів вважає, що повернення спірних земельних ділянок позивачу відповідає критерію законності: воно здійснюється у зв язку 3 порушенням органом місцевого самоврядування вимог Лісового кодексу України та Земельного кодексу України, що мають відповідати критеріям доступності, обгрунтованості, очікуваності, офіційні тексти зазначених нормативно-правових актів в актуальному стані $\epsilon$ публічними та загальнодоступними. Сумніви суб`єктів звернення у правильності 
Новітні досягнення та вектори розвитку сучасної юриспруденції

тлумачення та застосування цих норм судами не можуть свідчити про незаконність втручання в право власності.

За таких обставин колегія суддів дійшла висновку, що результат розгляду судом позову прокурора по суті не суперечить загальним принципам і критеріям правомірного втручання в право особи на мирне володіння майном, закладеним у статті 1 Першого протоколу і заперечення скаржника з цього приводу є безпідставними.

Отже, передання у приватну власність земельної ділянки, віднесеної до території зелених насаджень загального користування (земельної ділянки зелених зон і зелених насаджень міст), для будівництва й обслуговування індивідуального житлового будинку та господарських споруд без зміни її цільового призначення теж суперечило положенням Земельного кодексу України.

Враховуючи вищевикладене, вимоги прокурора про витребування з незаконного володіння Товариства з обмеженою відповідальністю «Грінінвест» на користь держави в особі Кабінету Міністрів України земельної ділянки площею 0,15 га 3 кадастровим номером 3210946200:01:042:0116 є доведеними та обгрунтованими, відповідачем не спростовними.

\section{3. Право на доступ до екологічної інформації як складова реалізації та захисту права особи на безпечне довкілля}

Реалізація права на безпечне довкілля $\epsilon$ неможливим поза створенням інформаційно-аналітичного забезпечення доступу до відомостей, що визначають стан використання природних ресурсів та природних об'єктів, характеризують рівень забруднення навколишнього природного середовища.

Право на доступ до екологічної інформації в умовах світової екологічної кризи, безсумнівно, $є$ базовим правом, без реалізації якого неможливо забезпечити інші екологічні права (зокрема, право на участь у прийнятті екологічно значущих рішень, право природокористування та інші). Право доступу до екологічної інформації $\epsilon$ передусім конституційним правом, адже воно закріплено в статті 50 Конституції України.

Відповідно до положень Орхуської конвенції визначено право кожного на доступ до інформації, участь громадськості у прийнятті екологічно важливих рішень та доступ до правосуддя з питань, що стосуються навколишнього середовища. 
Важливе значення у здійсненні права особи на безпечне довкілля відіграє інший міжнародний правовий акт Європейська конвенція про захист прав людини i основоположних свобод 1950 р., попри те, що вона безпосередньо не закріплює прямих матеріальних чи процесуальних екологічних прав, однак містить інші права і свободи, які опосередковано гарантують забезпечення основного матеріального права у сфері охорони довкілля - права на сприятливе навколишнє природне середовище (зокрема, це право на повагу до приватного i сімейного життя, закріплене статтею 8, право на свободу вираження поглядів, закріплене статтею 10).

Певною мірою екологічною «конституцією» України став Закон України «Про охорону навколишнього природного середовища», прийнятий 25.06.1991 р.. Статтею 9 зазначеного законодавчого акта гарантується кожному громадянину вільний доступ до інформації про стан навколишнього природного середовища (екологічна інформація) та вільне отримання, використання, поширення та зберігання такої інформації, за винятком обмежень, встановлених законом, а також громадським природоохоронним організаціям - вільний доступ до екологічної інформації.

Втім, під час вирішення питання про забезпечення права на допуск до екологічної інформації ключовим моментом $\epsilon$ віднесення тих чи інших відомостей саме до екологічної інформації.

Незважаючи на наявні в національному законодавстві (наприклад, Закони України «Про інформацію», «Про охорону навколишнього середовища») та міжнародних актах (зокрема, Орхуській Конвенції) визначення поняття «екологічна інформація», на практиці все ж виникають труднощі 3 віднесенням тієї чи іншої запитуваної інформації до екологічної. Тому в спірних правовідносинах саме від суду очікується в кожному випадку правильність установлення приналежності предмету запиту до екологічної інформації. Актуальним це $\epsilon$ також і у випадках, коли за даною інформацією звертаються громадські організації, яким в «екологічних» спорах Орхуська Конвенція передбачила право на звернення до суду.

Згідно із ч. 3 ст. 2 Орхуської Конвенції визначено, що екологічною інформацією є «будь-яка інформація в письмовій, аудіовізуальній, електронній чи будь-якій іншій матеріальній формі про: 
а) стан таких складових навколишнього середовища, як повітря і атмосфера, вода, грунт, земля, ландшафт і природні об'єкти, біологічне різноманіття та його компоненти, включаючи генетично змінені організми, та взаємодію між цими складовими;

б) фактори, такі як речовини, енергія, шум і випромінювання, а також діяльність або заходи, включаючи адміністративні заходи, угоди в галузі навколишнього середовища, політику, законодавство, плани і програми, що впливають або можуть впливати на складові навколишнього середовища, зазначені вище в підпункті a), і аналізі затрат і результатів та інший економічний аналіз і припущення, використані в процесі прийняття рішень 3 питань, що стосуються навколишнього середовища;

c) стан здоров'я та безпеки людей, умови життя людей, стан об'єктів культури і споруд тією мірою, якою на них впливає або може вплинути стан складових навколишнього середовища або через ці складові, фактори, діяльність або заходи, зазначені вище в підпункті б)».

Законом України «Про інформацію» встановлюється дещо відмінний нормативний підхід до розуміння категорії «інформації про стан використання природних ресурсів» як сукупності відомостей: «1) стан складових довкілля та його компоненти, включаючи генетично модифіковані організми, та взаємодію між цими складовими; 2) фактори, що впливають або можуть впливати на складові довкілля (речовини, енергія, шум i випромінювання, а також діяльність або заходи, включаючи адміністративні, угоди в галузі охорони навколишнього природного середовища; 3) стан здоров'я та безпеки людей, умови життя людей, стан об'єктів культури і споруд тією мірою, якою на них впливає або може вплинути; 4) інші відомостіта/або дані» [25].

Законом України «Про охорону навколишнього природного середовища» визначається, що екологічною інформацією $\epsilon$ це будь-яка інформація в письмовій, аудіовізуальній, електронній чи іншій матеріальній формі про: стан навколишнього природного середовища, його об'єктів (землі, вод, надр, атмосферного повітря, рослинного і тваринного світу та рівні їх забруднення; біологічне різноманіття і його компоненти (в т.ч. ГМО та їх взаємодію із об'єктами навколишнього природного середовища); джерела, фактори, матеріали, речовини, продукцію, енергію, фізичні фактори (шум, вібрацію, електромагнітне випромінювання, 
Новітні досягнення та вектори розвитку сучасної юриспруденції

радіацію), які впливають або можуть вплинути на стан навколишнього природного середовища та здоров'я людей; Загрозу виникнення i причини надзвичайних екологічних ситуацій, результати ліквідації цих явищ, рекомендації щодо заходів, спрямованих на зменшення їх негативного впливу на природні об'єкти та здоров'я людей; екологічні прогнози, плани і програми, заходи, в тому числі адміністративної, державної, екологічної політики, законодавства про охорону навколишнього природного середовища; витрати, пов'язані із здійсненням природоохоронних заходів за рахунок фондів охорони навколишнього природного середовища, інших джерел фінансування.

У справі «'Sdruženi Jihočeské Matky' (Співдружність матерів Південної Чехії) проти Чеської Республіки» (заява № 19101/03, від 10 липня 2006 року) [26] ЄСПЛ визначив, що спірні правовідносини в цій справі пов'язані з відмовою у наданні громадській екологічній організації документів і планів атомної електростанції в місті Темелін. У даному рішенні про прийнятність заяви Європейський суд з прав людини вперше застосував статтю 10 Конвенції у випадку, коли влада відмовила у запиті на доступ до адміністративних документів, хоча й не визнав їі порушення. У рішенні Європейський суд зазначив: «У результаті Суд вважає, що стаття 10 Конвенції не може витлумачуватись як така, що гарантує абсолютне право доступу до всіх технічних деталей, пов'язаних з будівництвом атомної станції, оскільки, на відміну від інформації про наслідки впливу останньої на довкілля, такі дані не можуть належати до тих, що становлять загальний інтерес» [27].

Таким чином, природоохоронній громадській організації було відмовлено у доступі не до інформації про стан забруднення довкілля, а безпосередньо про технічну документацію, пов'язану із організацією роботи атомної електростанції.

Постанова у справі “Sdruženi Jihočeské Matky", тим не менш, $\epsilon$ важливою, оскільки містить явне і незаперечне визнання застосування статті 10 у випадках відхилення запиту на доступ до публічних чи адміністративних документів. Право на доступ до адміністративних документів не $є$ абсолютним і дійсно може бути обмежене за умови пункту 2 статті 10, з чого випливає, що така відмова повинна бути передбачена законом, мати законну мету і повинна бути необхідною в демократичному суспільстві. 
Рішення ЄСПЛ від 10 липня 2006 р. надало додаткову підтримку та відкрило нові перспективи для громадян, журналістів та громадських організацій щодо доступу до адміністративних документів з питань, що становлять суспільний інтерес [26].

Правом доступу до екологічної інформації наділені такі суб'єкти, як:

- Фізичні особи, які захищають власні інтереси на забезпечення захисту права на безпечне довкілля;

- Громадські організації, метою функціонування яких відповідно до їх статутних документів $\epsilon$ забезпечення захисту екологічних прав громадян (що підтверджується як положеннями міжнародних актів, так і результатами національної судової практики, зокрема, прикладами $\epsilon$ рішення Касаційного адміністративного суду у складі Верховного Суду від 06 жовтня 2016 року у справі № 813/7397/13-а [28]).

Згідно із світовими стандартами, встановленими Орхуською Конвенцією правом на доступ до екологічної інформації наділена громадськість у розумінні «однієї або більшої кількості фізичних чи юридичних осіб, їхніх об'єднань, організацій або соціальних груп, які діють згідно з національним законодавством або практикою у спрямуванні дотримання вимог публічності використання природних ресурсів.

Орхуська Конвенція в якості суб'єктного складу правовідносин щодо забезпечення доступу до публічної екологічної інформації виокремлює «зацікавлену громадськість». Зазначена категорія згідно із міжнародними стандартами розуміється як громадськість, на яку справляє або може справити вплив процес прийняття рішень 3 питань, що стосуються навколишнього середовища, або яка має зацікавленість в цьому процесі; для цілей даного визначення недержавні організації, які сприяють охороні навколишнього середовища та відповідають вимогам національного законодавства, вважаються такими, що мають зацікавленість.

Міжнародними нормативними актами встановлюється обов'язок кожної держави, що ратифікувала Орхуську конвенцію із забезпечення доступу до публічної екологічної інформації для «зацікавленої громадськості», у разі: а) виявлення з їі боку достатньої заінтересованості чи, альтернативно, б) у разі, якщо зацікавлені громадські суб'єкти вважають, що мало місце порушення того чи іншого права, коли це обумовлено 
адміністративно-процесуальними нормами відповідної Сторони, мати доступ до процедури перегляду прийнятих рішень в суді та (або) іншому незалежному та неупередженому органі, заснованому згідно зі законом, з метою оскарження законності будь-якого рішення, дії або бездіяльності 3 правового та процесуального погляду за умови дотримання положень Статті 6, а також інших відповідних положень цієї Конвенції там, де це передбачено національним законодавством і без шкоди для пункту 3 [8].

Встановлення достатньої зацікавленості та обставин недотримання визначеного чинним законодавством права залежить від мети надання зацікавленій громадськості «широкого доступу до правосуддя». В цьому контексті для цілей вищенаведеного підпункту а) достатньо зацікавленості будь-якої неурядової організації, що відповідає вимогам, зазначеним у пункті 5 Статті 2. Для цілей підпункту б), наведеного вище, така організація також має право заявляти про порушення своїх прав.

Положення даного пункту 2 Орхуської конвенції не виключають можливості використання процедури попереднього перегляду адміністративним органом і не зачіпають вимоги щодо вичерпання адміністративних процедур перегляду перед зверненням до судових процедур перегляду в тих випадках, коли така вимога передбачена національним законодавством (пункт 2).

Крім процедур перегляду, передбачених вище пунктами 1 і 2 Орхуської конвенції, і без їх порушення, кожна зі Сторін забезпечує представникам громадськості, коли вони відповідають передбаченим законодавством критеріям, якщо такі є, доступ до адміністративних або судових процедур для оскарження дій або бездіяльності приватних осіб і громадських органів, які порушують положення національного законодавства, що стосується навколишнього середовища (пункт 3).

Крім цього, і без порушення вищенаведеного пункту 1 процедури, згадані вище в пунктах 1, 2, 3 Орхуської конвенції, мають забезпечувати адекватні та ефективні засоби правового захисту, включаючи у разі потреби засоби правового захисту у формі судової заборони, і бути справедливими, неупередженими, своєчасними і не пов язаними з непомірно великими витратами. Рішення, що приймаються відповідно до цієї Статті, надаються або реєструються у письмовій формі. Громадськість має доступ 
до рішень судів, а також, у міру можливостей, до рішень інших органів (пункт 4).

Отже, для забезпечення належної реалізації, зокрема, права особи на безпечне довкілля Орхуською конвенцією у статті 9 гарантується право доступу до екологічної інформації та його судового й адміністративного оскарження рішень, дій чи бездіяльності, що вчинені з порушенням права на доступ до інформації чи права на участь у процесі прийняття рішень 3 питань, що стосуються довкілля.

Пунктом 3 статті 9 Орхуської конвенції на i Договірні Сторони визначається зобов`язання забезпечувати доступ громадськості до оскарження діяльності владних суб'єктів та приватних осіб, внаслідок чого порушуються вимоги законодавства про охорону довкілля.

Згідно із Орхуською конвенцією закріплюється права представників громадськості на оскарження порушення національного законодавства у сфері довкілля незалежно від того, належать такі порушення до прав на інформацію і на участь громадськості при прийнятті рішень, гарантованих Орхуською конвенцією, чи ні (згідно з Керівництвом із провадження Орхуської конвенції (ОOH, 2000 рік), далі - Керівництво). Положення Орхуської конвенції гарантують громадськості доступ до правосуддя як на підставі власних положень, так і в порядку забезпечення дотримання національного природоохоронного законодавства.

Приписи нормативно-правових актів усіх рівнів щодо принципів, правил, вимог, обов`язків різноманітних суб`єктів, що стосуються утримання диких тварин, на усіх правових титулах (в усіх формах власності чи користування), в неволі чи в напіввільних умовах, $\epsilon$ «національним законодавством, що стосується навколишнього середовища» у розумінні пункту 3 статті 9 Орхуської конвенції. Порушення приписів цих нормативно-правових актів може бути предметом судового оскарження відповідно до статті 9 Орхуської конвенції.

До суб’єктів судового оскарження дотримання вимог доступу до публічної екологічної інформації як складової права особи на безпечне довкілля згідно з чинним законодавством України, і благодійні організації, адже згідно із Законом України «Про благодійну діяльність та благодійні організації» [29] сферами благодійної діяльності $\epsilon$, зокрема, екологія, охорона довкілля та 
захист тварин (стаття 3). Благодійній організації, до статутних цілей якої включено діяльність у сфері екології, охорони довкілля та захисту тварин, Орхуська конвенція надає право на доступ до правосуддя з питань довкілля у розумінні пункту 4 статті 9 цієї Конвенції.

Право судового оскарження дотримання правомірності надання доступу до екологічної інформації і юридичні особи приватного та публічного права, про що зазначається, зокрема, у рішенні від 03 липня 2019 року Касаційного адміністративного суду у складі Верховного Суду у справі № 826/3969/16 [30], де відповідно до позовних вимог приватного підприємства «Імператив плюс» до Публічного акціонерного товариства «Центренерго» щодо встановлення протиправності відмови відповідача надати на запит належним чином завірену копію паспорта потенційно небезпечного об'єкта Трипільської ТЕС (одна з позовних вимог). Колегія суддів у даній справі «дійшла висновку, що запитувана позивачем інформація стосується стану довкілля і становить суспільний інтерес. Позаяк ПАТ «Центренерго» володіє паспортом потенційно небезпечного об'єкта, відповідно й інформацією, яку містить цей документ, то як розпорядник цієї інформації повинен її надати. При цьому треба підкреслити, що якщо наявність обмежень щодо доступу до необхідної інформації, що містить відомості про паспорт потенційно небезпечного об’єкта (усієї чи певного їі обсягу), розпорядник публічної інформації, 3 дотриманням вимог частини другої статті 6 Закону України № 2939-VI, має мотивувати причини обмеження доступу до них. Якщо такі обмеження відсутні, то розпорядник зобов'язаний надати запитувані відомості. Судячи зі встановлених обставин цієї справи, відмова відповідача у наданні запитуваної інформації (паспорта потенційно небезпечного об'єкта) не була обгрунтованою. Понад те, якщо зважити, що така інформація стосується діяльності підприємства, яке негативно впливає на довкілля, відповідач як розпорядник не може ухилятися від іiі надання, покликаючись на свою статутну діяльність, якою, на його думку, обмежується обсяг його підзвітності/публічності як розпорядника інформації»

При цьому важливо підкреслити, що момент державної реєстрації юридичної особи приватного чи публічного права не 
повинен співвідноситися із моментом порушення права особи на безпечне довкілля.

Розпорядниками екологічної інформації згідно із статтею 13 Закону України «Про доступ до публічної інформації» $\epsilon$ [31]: 1) органи державної влади, інші державні органи, органи місцевого самоврядування, органи влади Автономної Республіки Крим, інші суб'єкти, відповідно до компетенції яких вимагається здійснення владних управлінських функцій згідно із чинним законодавством України та положеннями локальних актів; 2) юридичні особи публічного права, що уповноважені на надання інформації щодо використання бюджетних коштів; 3) суб'єкти делегованих владних повноважень згідно із законом чи договором, включаючи надання освітніх, оздоровчих, соціальних або інших державних послуг, - стосовно інформації, пов'язаної $з$ виконанням їхніх обов'язків; 4) суб'єкти господарювання, які займають домінуюче становище на ринку або наділені спеціальними чи виключними правами, або $\epsilon$ природними монополіями, - стосовно інформації щодо умов постачання товарів, послуг та цін на них.

За екологічною інформацією як видом публічної інформації був закріплений спеціальний правовий режим доступу, за яким така інформація, крім інформації про місце розташування військових об'єктів, не може бути віднесена до інформації 3 обмеженим доступом, тобто є відкритою і повинна надаватися за запитом (частина 3 Статті 13 Закону України «Про доступ до публічної інформації»).

Крім того згідно із положеннями пункту першого частини 2 статті 13 та частина 1 статті 7 Закону України «Про доступ до публічної інформації» заборонено віднесення інформації про стан довкілля до конфіденційної інформації [31].

Судовий контроль у сфері реалізації права на безпечне довкілля повинен бути спрямований на вирішення задачі досягнення балансу приватного та публічного інтересу у використанні та охороні природних ресурсів (ч. 2 ст. 8 Конвенції про захист основоположних прав і свобод людини). Зокрема, у справі «Гримковська проти України» [32] у п. 72 ЄСПЛ зазначає, що $\epsilon$ необхідним, по-перше, доведення Урядом, що перед ухваленням рішення про визначення вулиці Ч. частиною магістральної дороги M04 було підготовлено відповідне технікоекологічне обгрунтування, а після цього впроваджено розумну 
політику природокористування; по-друге, Уряд має довести, що заявниця мала реальну можливість брати участь у прийнятті відповідних рішень, включаючи можливість оскарження дій міської влади у незалежному органі, що у сукупності забезпечить досягнення справедливого балансу приватних та публічних інтересів.

Необхідно підкреслити, що з питань забезпечення доступу до екологічної інформації, забезпечення права людини на безпечне природне довкілля станом на 2020 рік ЄСПЛ розглянув декілька справ проти України, зокрема, вартими уваги $є$ рішення у справі «Дубецька та інші проти України» (заява № 30499/03 від 10.02.2011 р.) [33], у справі «Гримковська проти України» (заява № 38182/03 21.07.2011 р.) [32], у справі «Дземюк проти України» (заява № 42488/02 від 04.09.2014р.) [34].

Зазначені справи, попри те, що право пов'язуються із забезпеченням прав громадян на доступ до екологічної інформації, водночас містять важливі положення, які стосуються судового захисту екологічних прав і повинні братися до уваги українськими судами під час розгляду справ цієї категорії. Крім того, у справі «Гримковська проти України» містяться положення щодо впливу функціонування магістральної дороги, яка проходила через вулицю, на котрій проживала заявниця, ЄСПЛ не тільки визнав порушення статті 8 Конвенції, але й зробив деякі висновки щодо доступу інформації в даній справі: «Ні рішення національних судів, ні зауваження Уряду не містять доказів того, що такі гарантії, зокрема доступ громадськості до інформації про стан навколишнього середовища та прийняття рішень у період розроблення проекту з інвентаризації, існували» [27].

У справі «Дубецька та інші проти України» (заява № 30499/03 від 10.02.2011 р.) [33] ЄСПЛ обгрунтовує, що жодна стаття Конвенції не гарантує права на охорону природнього екологічного середовища як такого (див. рішення у справі «Кіртатос проти Греції» (Kyrtatos v. Greece), заява № 41666/98, пункт 52, ECHR 2003-VI). Також жодного питання не виникне, якщо оскаржувана шкода $є$ незначною у порівнянні з небезпекою навколишнього середовища, притаманною життю в кожному сучасному місті. Однак, може мати місце небезпідставна скарга за статтею 8 там, де екологічна небезпека досягає такого серйозного рівня, що призводить до суттєвого перешкоджання здатності заявника користуватися своїм житлом, мати приватне 
чи сімейне життя. Оцінка такого мінімального рівня $є$ відносною і залежить від усіх обставин справи, таких як інтенсивність та тривалість шкідливого впливу та його фізичний чи психологічний вплив на здоров'я або якість життя особи.

Національна судова практика містить окремі рішення щодо визначення основоположних засад здійснення права особи на безпечне довкілля в цілому, і зокрема, у сфері забезпечення доступу до публічної екологічної інформації. Зокрема, таким $\epsilon$ Рішення Касаційного адміністративного суду у складі Верховного Суду від 03.07.2019 № 826/3969/16. У зазначеній справі позивачеві було відмовлено у доступі до інформації про проведення паспортизації потенційно небезпечного об'єкта Трипільської TEC та надати копію Паспорта потенційно небезпечного об'єкту. Задовольняючи позовні вимоги, суд першої інстанції мотивував своє рішення тим, що паспорт потенційно небезпечного об'єкта є джерелом запитуваної інформації, а саме: екологічної інформації, та інформації, що становить суспільний інтерес, тому ПАТ «Центренерго» $\epsilon$ розпорядником зазначеної інформації та зобов'язаний її надати за запитом позивача. Апеляційна та касаційна інстанції відмовили у задоволенні поданих відповідних скарг.

Варто відзначити, що у світі $є$ відомою достатньо ефективна практика функціонування екологічних судів (земельних судів, водних судів).

В якості прикладу необхідно навести Земельний суд штату Гавайї (Hawaii (State) Land Court) (заснований у 1903 році), Водний Суд Монтани (The Montana Water Court) (функціонування якого розпочинається із 1979 року) тощо. Функціональне спрямування діяльності таких судових органів полягає у розгляді та вирішенні земельних, водних, лісових та інших природоресурсних спорів; здійсненні адміністративних повноважень щодо організації управління державними чи місцевими реєстрами спеціальних прав на використання природних об'єктів, включаючи i визначення обгрунтованості підстав їх набуття та припинення; компетенція із гарантування дієвості механізму відшкодування екологічної шкоди та організації контролю у відповідній сфері. Однією із складових належного рівня ефективності функціонування таких квазісудових органів в Сполучених Штатах Америки $є$ включення до його штатної структури не лише суддів та працівників суддівського самоврядування та апарату, a i 
відповідних вузько профільних спеціалістів-експертів, до яких, зокрема, відносяться геодезисти, екологи тощо. Варто наголосити, що подібна практика функціонування «квазісудових» органів $\epsilon$ притаманною для ряду штатів Північної Америки функціонують, у разі наявності підвищеного публічного інтересу у оперативному розгляді та вирішенні спорів як у сфері використання природних ресурсів, так і на стадії оформлення відповідних спеціальних дозволів. Варто відзначити, що в Сполучених Штатах Америки діє принцип "first intime is first in right", що полягає у пріоритетності забезпечення прав і свобод людини на забезпечення її потреб у природокористуванні.

\section{Висновок}

Отже, правом особи на безпечне довкілля $є$ право особи на забезпечення сприятливості антропогенного та природного навколишнього середовища, що характеризується показниками ефективності здійснення використання природних ресурсів на засадах раціональності та екологічності, стану охорони здоров'я населення тощо.

Проблемами ефективності реалізації та захисту права особи на безпечне довкілля є: 1) нормативна колізійність підходів до його розуміння відповідно до положень чинного національного законодавства України та світових стандартів; 2) стагнація систематизаційних процесів у сфері використання природних ресурсів та охорони навколишнього природного середовища; 3) поліаспектність предметної національної судової юрисдикції, що спричинює неоднозначність підходів до її застосування; 4) недосконалість механізму захисту публічного інтересу, зокрема, у частині залучення зацікавленої громадськості як його носія; 5) доцільність перегляду підходів до розуміння предмету доказування у справах про порушення права особи на безпечне довкілля, що покладається на носіїв такого права чи інтересу, а не на осіб, які порушили суб'єктивні екологічні права або ж вимоги екологічного законодавства.

\section{Література:}

1. Results Overview. Environmental Performance Index. URL.: https://epi.yale.edu/epi-results/2020/component/epi

2. Environmental Performance Index. URL: https://epi.yale.edu 
3. Конституція України: Закон України від 28 червня 1996 року. URL.: https://zakon.rada.gov.ua/laws/show/254к/96вр\#Text

4. Про охорону навколишнього природного середовища: Закон України від 25 червня 1991 року. URL.: https:// zakon.rada.gov.ua/laws/show/1264-12\#Text

5. Адміністративна відповідальність в Україні: навч. посіб. / Комзюк А. Т., Гуменюк В. А., Джагупов Г. В. [та ін. ]; за заг. ред. А. Т. Комзюка. Харків: Видавництво Харківський Національний університет внутрішніх справ, 2007. 80 с.

6. Стойко С.М., Койнова І.Б. Сучасні види антропогенного впливу на життєве середовище. Український географічний журнал. 2012. № 1. С. 50-57.

7. Декларация Конференции ООН по проблемам окружающей человека среды: международный документ от 16 июня 1972 г. URL: https://zakon.rada.gov.ua/laws/show/995_454

8. Конвенція про доступ до інформації, участь громадськості в процесі прийняття рішень та доступ до правосуддя з питань, що стосуються довкілля (Орхуська конвенція) : міжнародний документ ООН від 25 червня 1998 р. (ратифікований Законом України від 6 липня 1999 р. № 832-XIV). Верховна Рада України. Офіційний вісник України. 2010. № 33. С. 12. Ст. 1191. URL: https://zakon.rada.gov.ua/laws/show/994_015

9. Земельний кодекс України: Закон України від 25 жовтня 2001 p. № 2768-III. Відомості Верховної Ради України (ВВР). 2002. № 3-4. Ст. 27.

10.Водний кодекс України від 06.06.1995. № 213/95-ВР. Відомості Верховної Ради України. 1995. № 24. Ст. 189.

11.Кодекс України про надра від 27.07.1994 р. Відомості Верховної Ради України. 1994. № 36. Ст. 340

12.Лісовий кодекс України від 21.01.1994 р. (зі змінами і допов.). Відомості Верховної Ради України. 1994. № 17. Ст. 99.

13. Копєйчиков В. Питання кодифікації законодавства України. Вісник Академії правових наук України. 1994. № 2. С. 44-52.

14.Наливайко Л. Р. Конституційно-правові засади та зміст екологічної функції Української держави. Університетські наукові записки. Часопис Хмельницького університету управління та права. 2006. № 1 (17). С. 181-185.

15.Наливайко Л. Р. Державний лад України: поняття, система, гарантії: дис. ... Д-ра юрид. наук: 12.00.01. Харків, 2010. 535 с. 
16. Легеза Ю. О. Напрямки розвитку нормативних засад публічного управління у сфері використання природних ресурсів. Юридичний науковий електронний журнал. 2017. № 4. С. 90-93.

17.Кобецька Н.Р. Екологічні права громадян України: автореф. ... дис. канд. юрид. наук: 12.00.06. Київ, 1998. 16 с.

18. Шепель М.А. Публічний інтерес та легітимні очікування як складові судового захисту права на безпечне довкілля. Південноукраїнський правничий часопис. 2019. № 3. С. 158-163.

19.Экологический кодекс Республики Казахстан. URL.: https://adilet.zan.kz/rus/docs/K2100000400

20. Шемшученко Ю.С., Костицький В.В. Про соціальну обумовленість сучасних проблеми теорії та методології екологічного права. Екологічне право України. 2017. № 1-2. С. 66-74.

21.Угода про асоціацію між Україною та Європейським Союзом. URL:http://zakon3.rada.gov.ua/laws/show/984_011

22. Про адміністративну процедуру: проєкт Закону України № 9456 від 28 грудня 2018 p. URL: http://w1.c1.rada.gov.ua/pls/ zweb2/webproc4_1?pf3511=65307

23. Рішення Конституційного Суду України у справі за конституційним поданням 50 народних депутатів України щодо офіційного тлумачення окремих положень частини першої статті 4 Цивільного процесуального кодексу України (справа про охоронюваний законом інтерес). URL.: https://zakon.rada.gov.ua/ laws/show/v018p710-04\#Text

24. Постанова Північного апеляційного господарського суду у справі № 911/3447/17 від 29 січня 2019 року. URL: https://verdictum.ligazakon.net/document/92437896

25.Про інформацію: Закон України від 2 жовтня 1992 року № 2657-XII. Відомості Верховної Ради України. 1992. № 48. Ст. 650.

26.Справа Sdruženi Jihočeské Matky. Співдружність матерів Південної Чехії проти Чеської Республіки. Рішення Європейського суду з прав людини щодо доступу до інформації 10 липня 2006 року № 19101/03 / За заг. редакцією Шевченко Т.С., Розкладай I.Є. К.: Москаленко О.М., 2014. 200 с.

27.Конвенція про захист прав людини і основоположних свобод: ратифікована Законом України № 475/97-ВР від 17 липня 1997 р. Офіційний вісник України. 1998. № 13, № 32.

28.Ухвала Касаційного адміністративного суду у складі Верховного Суду від 06 жовтня 2016 року у справі 
№ 813/7397/13-a. URL.: https://reyestr.court.gov.ua/Review/ 62028155

29.Про благодійну діяльність та благодійні організації: Закон України від 5 липня 2012 року № 5073-VI. https://zakon.rada.gov.ua/ laws/show/5073-17\#Text

30.Постанова Касаційного адміністративного суду у складі Верховного Суду від 03 липня 2019 року № 826/3969/16. URL: http://www.reyestr.court.gov.ua/Review/82819949

31.Про доступ до публічної інформації: Закон України від 13 січня 2011 року № 2939-VI. Відомості Верховної Ради України. 2011. № 32. Ст. 314.

32.Справа «Гримковська проти України»: Рішення Європейського Суду з прав людини від 21 липня 2011 року № 38182/03. URL: https://zakon.rada.gov.ua/laws/show/974_729 \#Text

33.Справа «Дубецька та інші проти України»: Рішення Європейського Суду з прав людини від 10 лютого 2011 року № 30499/03. URL: https://zakon.rada.gov.ua/laws/show/ 974_689\#Text

34.Справа «Дземюк проти України»: Рішення Європейського Суду з прав людини від 4 вересня 2014 року № 42488/02. URL: https://zakon.rada.gov.ua/laws/show/974_a51\#Text 